Article

\title{
Discriminable Sensing Response Behavior to Homogeneous Gases Based on $\mathrm{n}-\mathrm{ZnO} / \mathrm{p}-\mathrm{NiO}$ Composites
}

\author{
Wen-Dong Zhou ${ }^{1}\left(\right.$, Davoud Dastan ${ }^{2}$, Jing Li ${ }^{3}$, Xi-Tao Yin ${ }^{3, *}$ and Qi Wang ${ }^{1,3, * \mathbb{C}}$ \\ 1 School of Chemical Engineering, University of Science and Technology Liaoning, Anshan 114051, China; \\ zhouwendong1986@163.com \\ 2 School of Materials Science and Engineering, Georgia Institute of Technology, Atlanta, GA 30332, USA; \\ davoud.dastan@mse.gatech.edu \\ 3 The Key Laboratory of Chemical Metallurgy Engineering of Liaoning Province, University of Science and \\ Technology Liaoning, Anshan 114051, China; Lijing_as321@163.com \\ * Correspondence: yxtaj@163.com (X.-T.Y.); wangqi8822@sina.com (Q.W.); Tel./Fax: +86-0412-5929557 (Q.W.)
}

Received: 12 March 2020; Accepted: 16 April 2020; Published: 20 April 2020

\begin{abstract}
Metal oxide semiconductor (MOS) gas sensors have the advantages of high sensitivity, short response-recovery time and long-term stability. However, the shortcoming of poor discriminability of homogeneous gases limits their applications in gas sensors. It is well-known that the MOS materials have similar gas sensing responses to homogeneous gases such as $\mathrm{CO}$ and $\mathrm{H}_{2}$, so it is difficult for these gas sensors to distinguish the two gases. In this paper, simple sol-gel method was employed to obtain the $\mathrm{ZnO}-x \mathrm{NiO}$ composites. Gas sensing performance results illustrated that the gas sensing properties of composites with $x>0.425$ showed a p-type response to both $\mathrm{CO}$ and $\mathrm{H}_{2}$, while the gas sensing properties of composites with $x<0.425$ showed an $\mathrm{n}$-type response to both $\mathrm{CO}$ and $\mathrm{H}_{2}$. However, it was interesting that $\mathrm{ZnO}-0.425 \mathrm{NiO}$ showed a p-type response to $\mathrm{CO}$ but an discriminable response (n-type) to $\mathrm{H}_{2}$, which indicated that modulating the p-type or n-type semiconductor concentration in $\mathrm{p}$-n composites could be an effective method with which to improve the discriminability of this type of gas sensor regarding $\mathrm{CO}$ and $\mathrm{H}_{2}$. The phenomenon of the special gas sensing behavior of $\mathrm{ZnO}-0.425 \mathrm{NiO}$ was explained based on the experimental observations and a range of characterization techniques, including XRD, HRTEM and XPS, in detail.
\end{abstract}

Keywords: gas sensors; homogenous gases; discriminable response; selectivity; $\mathrm{ZnO}-\mathrm{NiO}$ composite

\section{Introduction}

Various gases, including blast furnace gas, coke oven gas, water gas and other secondary gases are used as reducing agents and fuels in metallurgical and chemical production. It is well-known that $\mathrm{CO}$ and $\mathrm{H}_{2}$ can be used as reactants for chemical and metallurgical production. $\mathrm{H}_{2}$ is an explosive and flammable gas [1,2], while CO is a toxic gas [3,4]. The leakages of those gases during the process of storage and transportation lead to some security issues [5]. Furthermore, it is difficult to differentiate these two gases, as they are colorless, odorless, homogeneous and reducing gases. Therefore, it is necessary to design and fabricate sensors that can accurately identify whether the leaking gas is $\mathrm{CO}$ or $\mathrm{H}_{2}$. Metal oxide semiconductor (MOS) gas sensors have been investigated for gas sensing detection of toxic and flammable gases [6-8].

Among the MOS gas sensors, $\mathrm{ZnO}$ and $\mathrm{SnO}_{2}$ as n-type metal oxide semiconductors (MOSs) have attracted much attention due to their excellent electrical properties and stable chemical and thermal features [9-11]. Moreover, other n-type MOSs, such as $\mathrm{Fe}_{2} \mathrm{O}_{3}$ [12], $\mathrm{WO}_{3}$ [13], $\mathrm{In}_{2} \mathrm{O}_{3}$ [14] and $\mathrm{TiO}_{2}$ [15], and p-type $\mathrm{MOS}$ such as $\mathrm{NiO}$ [16], $\mathrm{Co}_{3} \mathrm{O}_{4}$ [17], $\mathrm{Cr}_{2} \mathrm{O}_{3}$ [18], $\mathrm{CuO}$ [19] and $\mathrm{Mn}_{3} \mathrm{O}_{4}$ [20] have 
been extensively studied. As a typical n-type MOS with wide band gap energy of $3.37 \mathrm{eV}$ at room temperature [21,22], $\mathrm{ZnO}$ has been widely employed because of its unique sensing properties and widespread applications [23]. In terms of performance, the most important indexes of ZnO-based gas sensors are selectivity, sensitivity, response-recovery speed (time) and stability (marked as " $4 S^{\prime \prime}$ ). Unfortunately, the main disadvantage of $\mathrm{ZnO}$-based gas sensors is the poor selectivity [24]; it is difficult for the $\mathrm{ZnO}$-based gas sensors to differentiate the aforementioned two gases because of their similar behaviors.

Some strategies have been employed to overcome the low selectivity of this kind of gas sensor, including regulation of the optimal operating temperature [25-27]; doping or loading of a noble metal [28-32]; modification of chemical composition, morphology and microstructure of the sensor materials [33-35]; and construction of n-n [36-39] or p-n junction [40-47]. Among them, the construction of $\mathrm{p}-\mathrm{n}$ junction is expected to be a promising strategy due to the fact that the active sites of the $\mathrm{p}-\mathrm{n}$ composites are different for the target gases. However, although the discriminability of gas sensors based on $\mathrm{ZnO}$ has been enhanced, these sensors could not precisely distinct the homogenous gases. Thus, poor discriminability of gas sensors for homogenous gases is still a challenge which limits the improvement in the performance of this type of gas sensor.

In this paper, $\mathrm{ZnO}-x \mathrm{NiO}$ composites were designed and synthesized via a facile sol-gel process, and their gas sensing performances were systematically studied. We illustrated that the poor discriminability of gas sensors based on $\mathrm{ZnO}$ against $\mathrm{CO}$ and $\mathrm{H}_{2}$ can be enhanced via changing the amounts of the $\mathrm{p}$ or $\mathrm{n}$-type oxide materials in $\mathrm{p}-\mathrm{n}$ composites. The results of gas sensing properties of $\mathrm{ZnO}-x \mathrm{NiO}$ sensors indicated that the $\mathrm{ZnO}-0.425 \mathrm{NiO}$ sensor sintered at $550{ }^{\circ} \mathrm{C}$ and operated at $350{ }^{\circ} \mathrm{C}$ showed n-type response for $\mathrm{H}_{2}$ and p-type response for $\mathrm{CO}$; the special behavior of the opposite gas sensing responses of the $\mathrm{ZnO}-0.425 \mathrm{NiO}$ composite to $\mathrm{CO}$ and $\mathrm{H}_{2}$ suggests that the $\mathrm{ZnO}-0.425 \mathrm{NiO}$ composite can accurately differentiate individual $\mathrm{CO}$ and $\mathrm{H}_{2}$. It is worth noting that $\mathrm{ZnO}-0.425 \mathrm{NiO}$ composite can accurately identify whether the gas is $\mathrm{CO}$ or $\mathrm{H}_{2}$, rather than selectively detecting the mixture of $\mathrm{CO}$ and $\mathrm{H}_{2}$. Hence, we propose an effective method by adjusting the components of the composites to solve the poor discriminability problem of the $\mathrm{ZnO}$-based sensors so that they can accurately distinguish $\mathrm{CO}$ and $\mathrm{H}_{2}$. Furthermore, the phenomenon of the abnormal sensing behavior of $\mathrm{ZnO}-0.425 \mathrm{NiO}$ for $\mathrm{H}_{2}$ and $\mathrm{CO}$ is explained in detail.

\section{Experimental Details}

\subsection{Chemicals}

Zinc acetate dehydrate $\left(\mathrm{Zn}\left(\mathrm{CH}_{3} \mathrm{COO}\right)_{2} \cdot 2 \mathrm{H}_{2} \mathrm{O}\right)$, nickel chloride hexahydrate $\left(\mathrm{NiCl}_{2} \cdot 6 \mathrm{H}_{2} \mathrm{O}\right)$, polyvinyl pyrrolidone (PVP, K-30), absolute methanol $\left(\mathrm{CH}_{3} \mathrm{OH}\right)$, ethyl cellulose (M70) and $\alpha$-terpineol $\left(\mathrm{C}_{10} \mathrm{H}_{18} \mathrm{O}\right)$ were purchased from Sinopharm Chemical Reagent Co. LTD (Beijing, China). All the reagents were of analytical grade and used directly without further purification.

\subsection{Preparation of Materials}

$\mathrm{ZnO}-x \mathrm{NiO}$ composites with different molar ratios of $\mathrm{Zn} / \mathrm{Ni}$ were prepared using a sol-gel method $[48,49]$ in the following three steps. (a) $1 \mathrm{~g}$ of $\mathrm{Zn}\left(\mathrm{CH}_{3} \mathrm{COO}\right)_{2} \cdot 2 \mathrm{H}_{2} \mathrm{O}$ was dissolved into a mixture of $5 \mathrm{~mL}$ distilled water and $10 \mathrm{ml}$ methanol to form a solution; then, $0.1 \mathrm{~g}$ of PVP was added into the above solution and stirred until all PVP were completely dissolved. Next, the solution was heated at $75{ }^{\circ} \mathrm{C}$ for $1 \mathrm{~h}$ until the $\mathrm{ZnO}$ gel formed. (b) $\mathrm{NiCl}_{2} \cdot 6 \mathrm{H}_{2} \mathrm{O}$ was added into the $\mathrm{ZnO}$ gel and the mixture was stirred to form a homogeneous solution, which was further dried at $150^{\circ} \mathrm{C}$ for $1 \mathrm{~h}$ at ambient condition. (c) The product was grounded for $10 \mathrm{~min}$ to obtain the $\mathrm{ZnO}-x \mathrm{NiO}$ powder, which was further annealed at $550^{\circ} \mathrm{C}$ in air atmosphere for $3 \mathrm{~h}$. For convenience, the composites with a molar ratio of $\mathrm{Zn}: \mathrm{Ni}=1: x$ were named $\mathrm{ZnO}-x \mathrm{NiO}(x=0.111,0.350,0.400,0.425,0.429,0.450,0.667,1.000)$, respectively. Pristine $\mathrm{ZnO}$ was prepared using the same steps, but without the addition of $\mathrm{NiCl}_{2} \cdot 6 \mathrm{H}_{2} \mathrm{O}$ in the second step. Additionally, $\mathrm{ZnO}-0.425 \mathrm{NiO}$ was annealed at 500,550 and $600{ }^{\circ} \mathrm{C}$ to explore the influence of sintering temperature on gas sensing properties. 


\subsection{Fabrication of Gas Sensors}

$\mathrm{ZnO}-x \mathrm{NiO}$ gas sensors were prepared by printing $\mathrm{ZnO}-x \mathrm{NiO}$ composites and platinum $(\mathrm{Pt}) \mathrm{on}$ aluminum oxide substrate as the sensing materials and digital electrode, respectively. Silk screen printing was employed to fabricate the gas sensors as follows. (a) The aluminum oxide substrate was printed with Pt electrodes, and then roasted at $800^{\circ} \mathrm{C}$ for $3 \mathrm{~h}$ in muffle furnace; (b) $1 \mathrm{~g}$ of ethyl cellulose was added into $10 \mathrm{~mL}$ of $\alpha$-terpineol, and then the mixture was stirred and heated at $80{ }^{\circ} \mathrm{C}$ for $1 \mathrm{~h}$ to prepare the binder; (c) $1 \mathrm{~g}$ of $\mathrm{ZnO}-x \mathrm{NiO}$ composite and $0.1 \mathrm{~g}$ of the binder were mixed and ground for 20 min to obtain the paste; (d) the paste was printed on the alumina substrate with digital electrodes using silk screen printing, and then the fabricated sensor was annealed at $550{ }^{\circ} \mathrm{C}$. Figure $1 \mathrm{a}$ depicts a typical image of the fabricated sensor.

(a)

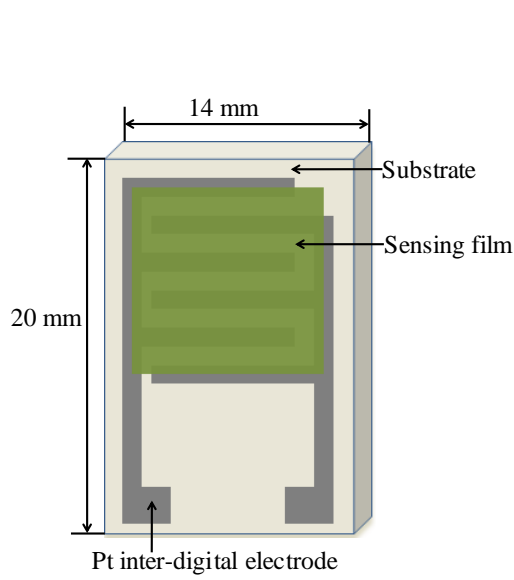

(b)

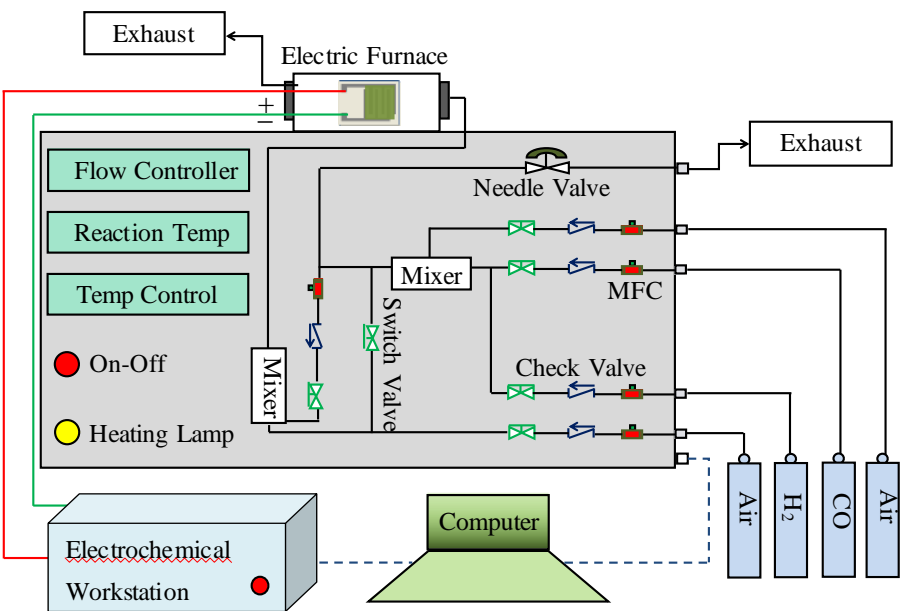

Figure 1. Schematic diagram of (a) the sensor component and (b) the gas sensing measurement system.

\subsection{Gas Sensing Measurements}

Figure $1 \mathrm{~b}$ depicts a typical image of the gas sensing system which consists of three main parts: an electric furnace, an electrochemical workstation (CHI660E, Chenhua Instruments Inc, Changsha, China) and a gas distribution system with a mass flow device. The specific process for the analysis of gas sensing performance is as follows. (a) The sensor was placed in an electric furnace and the two electrodes from the sensor were connected to the electrodes of the electrochemical workstation through platinum wire. (b) Air was used as carrier gas; the gas mass flow meter was used to monitor gas flow; the total flow rate through the electric furnace was maintained at $500 \mathrm{~mL} / \mathrm{min}$. (c) A constant voltage of $5 \mathrm{~V}$ was applied to the sensor and the I-t curve was obtained by means of an electrochemical workstation, the resistance was calculated based on Ohm's law $(\mathrm{R}=\mathrm{V} / \mathrm{I})$. In this paper, "Ra" stands

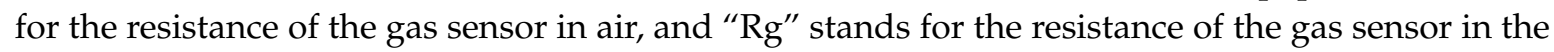
presence of target gas. The response of a sensor was defined as response $(R)=R a / R g-1$.

\subsection{Material Characterizations}

The crystal structures of $\mathrm{ZnO}$ and $\mathrm{ZnO}-x \mathrm{NiO}$ composites were studied using $\mathrm{X}$-ray diffraction (XRD, X'Pert Pro, PANalytical B.V., Almelo, The Netherlands), using copper K $\alpha 1$ radiation $(\lambda=$ $1.542 \AA$ ); the scanning range was $10-90^{\circ}$ and the scanning speed was $10^{\circ} / \mathrm{min}$. The compositional and surface physico-chemical states of $\mathrm{ZnO}-0.425 \mathrm{NiO}$ were further characterized. The microstructure of $\mathrm{ZnO}-0.425 \mathrm{NiO}$ was studied by means of high resolution transmission electron microscopy (HRTEM, JEM-2100F, Tokyo, Japan), and energy dispersive X-ray spectroscopy (EDS). The surface physico-chemical states of $\mathrm{ZnO}$ and $\mathrm{ZnO}-0.425 \mathrm{NiO}$ were researched using $\mathrm{X}$-ray photoelectron spectroscopy (XPS, ThermoFisher, Waltham, MA, USA) with Al K $\alpha$ radiation. The phase identifications 
of $\mathrm{ZnO}-0.425 \mathrm{NiO}$ composite and pristine $\mathrm{ZnO}$ were confirmed by means of Raman spectrometer (Raman, DXR2, ThermoFisher, Waltham, MA, USA) with a laser wavelength of $514 \mathrm{~nm}$ under ambient conditions. The photoluminescence spectra (PL, HITACHI, Tokyo, Japan) were used with the Xe laser of $325 \mathrm{~nm}$ to study the recombination of electrons-holes at the ambient condition.

\section{Results and Discussion}

\subsection{Structural and Morphological Characterization}

$\mathrm{XRD}$ of $\mathrm{ZnO}$ and $\mathrm{ZnO}-x \mathrm{NiO}$ composites annealed at $550{ }^{\circ} \mathrm{C}$ were carried out to illustrate the crystal structure of $\mathrm{ZnO}$ and the influence of $\mathrm{Ni}$ doping on the crystal structure $\mathrm{ZnO}$. As shown in Figure $2 \mathrm{a}$, all diffraction peaks can be indexed as individual $\mathrm{ZnO}$ and $\mathrm{NiO}$. The diffraction peaks located at about $2 \theta=37.09^{\circ}, 43.09^{\circ}, 62.59^{\circ}, 75.05^{\circ}$ and $79.02^{\circ}$ are corresponding to the (111), (200), (220), (311) and (222) lattice planes of the cubic $\mathrm{NiO}$ (reference code: 01-089-7130, a = b = c = 4.1944 $\AA$, space group Fm-3m), respectively. Diffraction peaks centered at $2 \theta=31.69^{\circ}, 34.38^{\circ}, 36.18^{\circ}, 47.46^{\circ}, 56.46^{\circ}$, $62.76^{\circ}, 66.22^{\circ}, 67.81^{\circ}, 68.92^{\circ}, 72.47^{\circ}, 76.79^{\circ}, 81.26^{\circ}$ and $89.42^{\circ}$ correspond to the (100), (002), (101), (102), (110), (103), (200), (112), (201), (004), (202), (104) and (203) Miller indexes of hexagonal ZnO (reference code:01-079-0207, $\mathrm{a}=\mathrm{b}=3.2568 \AA, \mathrm{c}=5.2125 \AA$, space group P63mc), respectively.

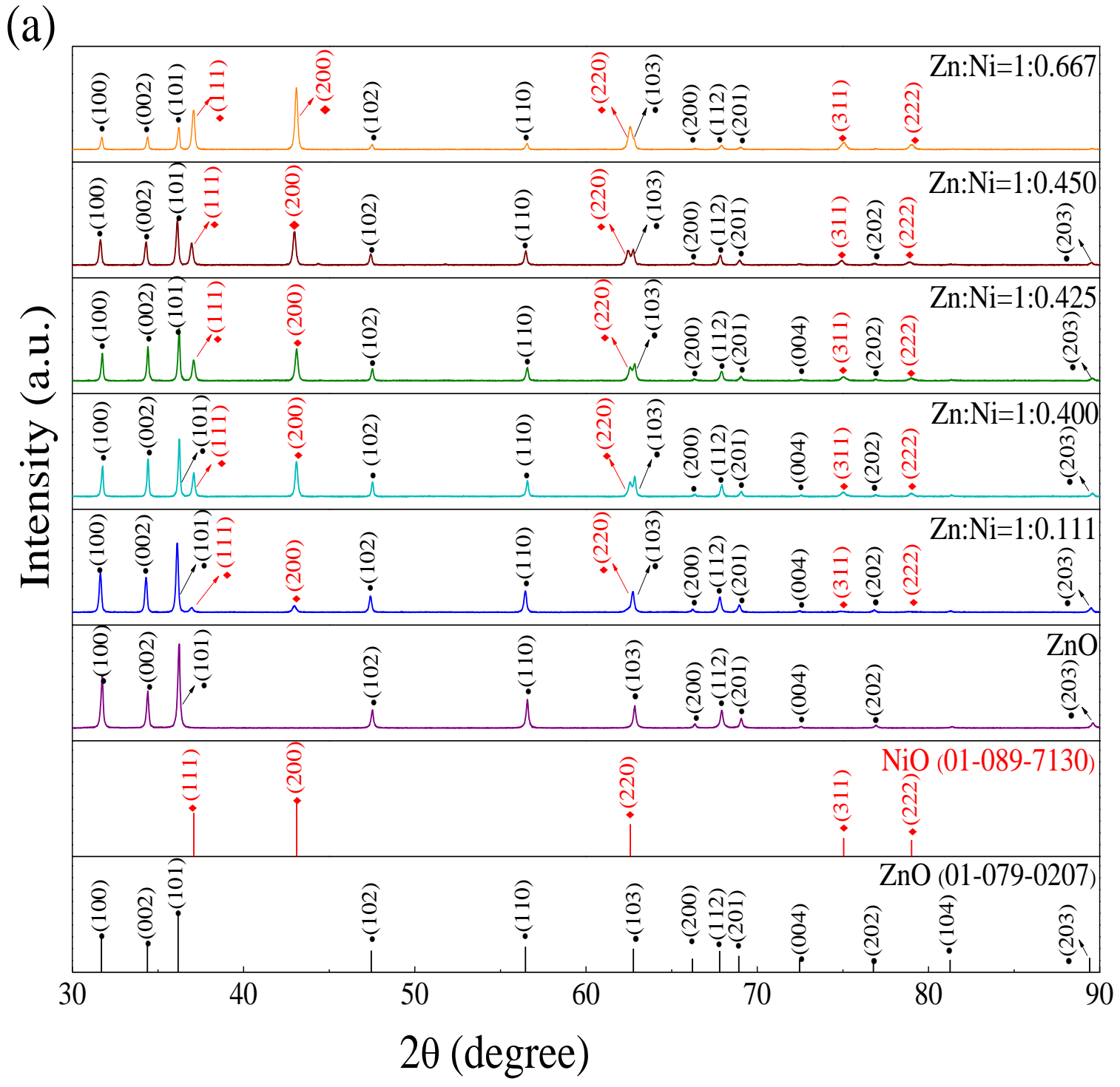

Figure 2. Cont. 


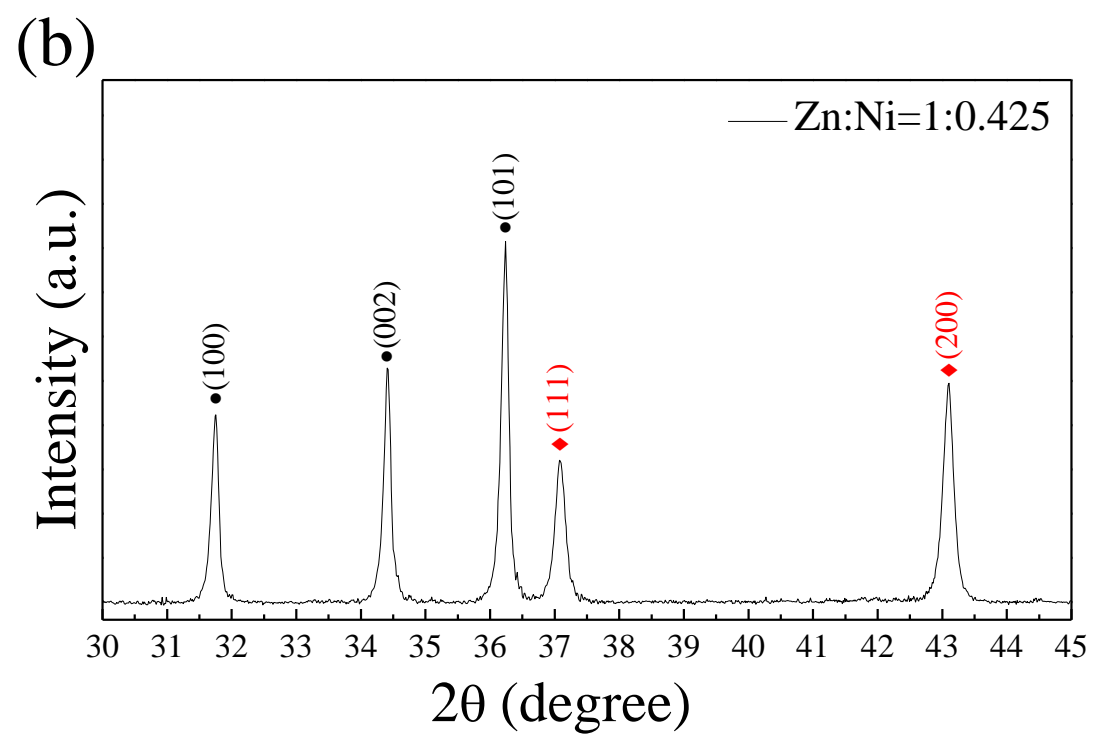

Figure 2. (a) XRD patterns of pristine $\mathrm{ZnO}$ and $\mathrm{ZnO}-x \mathrm{NiO}$ composites annealed at $550{ }^{\circ} \mathrm{C}$ with different molar ratios of $\mathrm{Zn}: \mathrm{Ni}$. (b) Partially enlarged XRD patterns of $\mathrm{ZnO}-0.425 \mathrm{NiO}$ composite annealed at $550{ }^{\circ} \mathrm{C}$.

The grain sizes of $\mathrm{ZnO}$ and $\mathrm{NiO}$ in $\mathrm{ZnO}-0.425 \mathrm{NiO}$ were evaluated using theoretical Debye-Scherer equation (Equation (1)).

$$
\mathrm{d}=\frac{0.89 \lambda}{\beta \cos \theta}
$$

where the wavelength $\lambda$ of X-ray was $0.1542 \mathrm{~nm} ; \theta$ is the Bragg diffraction angle $(\theta)$; and $\beta$ is full width at half maximum, which was calculated based on the most intense peaks of $\mathrm{ZnO}$ and $\mathrm{NiO}$ in Figure $2 \mathrm{~b}$. The peaks of (100), (002) and (101) planes for $\mathrm{ZnO}$ and the peaks of (111) and (200) planes for NiO were considered to evaluate the crystal structure factors, as summarized in Table 1 . The average grain sizes of $\mathrm{ZnO}$ and $\mathrm{NiO}$ in $\mathrm{ZnO}-0.425 \mathrm{NiO}$ composite were obtained as 63.42 and $44.61 \mathrm{~nm}$, respectively, which illustrate the formation of nanostructured materials.

Table 1. Parameters for the calculation of crystallite sizes.

\begin{tabular}{cccccc}
\hline Metal Oxide & $\begin{array}{c}\text { Diffraction } \\
\text { Planes }\end{array}$ & $\begin{array}{c}\text { Diffraction } \\
\text { Angles (deg.) }\end{array}$ & FWHM ( $\beta$ ) & $\begin{array}{c}\text { Crystallite } \\
\text { Size (nm) }\end{array}$ & $\begin{array}{c}\text { Average Size } \\
(\mathbf{n m})\end{array}$ \\
\hline $\mathrm{ZnO}$ & $(100)$ & 31.69 & 0.1314 & 62.24 & 63.42 \\
& $(002)$ & 34.38 & 0.1248 & 65.99 & \\
$\mathrm{NiO}$ & $(101)$ & 36.18 & 0.1334 & 62.04 & 44.61 \\
& $(111)$ & 37.09 & 0.1877 & 44.21 & 45.01 \\
\hline
\end{tabular}

In the XRD patterns, there are only diffraction peaks of individual $\mathrm{ZnO}$ and $\mathrm{NiO}$; no unwished peaks of ternary phases associated with $\mathrm{Ni}$ and $\mathrm{Zn}$-based were observed. In addition, compared with the XRD pattern of pristine $\mathrm{ZnO}$, the center of each diffraction peak in the $\mathrm{ZnO}-x \mathrm{NiO}$ composite was not shifted, which indicates that hexagonal $\mathrm{ZnO}$ and cubic $\mathrm{NiO}$ crystals are formed after sintering. Moreover, the $\mathrm{n}-\mathrm{ZnO} / \mathrm{p}-\mathrm{NiO}$ heterojunctions form at the interface of the grains without changing the crystal structure of $\mathrm{ZnO}$. Thus, the effect of variation in the crystal structure of $\mathrm{ZnO}$ on sensor response should be eliminated and we only focus to the influence of $\mathrm{p}-\mathrm{n}$ heterojunctions on the gas sensing properties. Moreover, $\mathrm{ZnO}$ and $\mathrm{ZnO}-x \mathrm{NiO}$ composites with high purity and high-crystallinity have been successfully prepared.

The intensity of diffraction peaks in the XRD spectra of $\mathrm{ZnO}$ decreases, gradually while the intensity of diffraction peaks of $\mathrm{NiO}$ increases gradually upon an increase in the molar ratio of nickel, 
which indicates that $\mathrm{ZnO}-x \mathrm{NiO}$ composites with different nickel contents were obtained by regulating the concentration of $\mathrm{n}$-/p-type semiconductors.

Therefore, the obtained XRD results of $\mathrm{ZnO}-x \mathrm{NiO} \mathrm{p}-\mathrm{n}$ junction with various $\mathrm{Ni}$ contents support the following discussion for the gas sensing phenomenon of $\mathrm{ZnO}-x \mathrm{NiO}$ composite that strongly interferes with the target gasses. The microstructure and the elemental composition of the $\mathrm{ZnO}-0.425 \mathrm{NiO}$ composite annealed at $550{ }^{\circ} \mathrm{C}$ were further confirmed by TEM, HRTEM and EDS analysis. Figure 3 a depicts the TEM image of $\mathrm{ZnO}-0.425 \mathrm{NiO}$ composite. It can be conspicuously seen that $\mathrm{ZnO}$ and $\mathrm{NiO}$ particles with uneven sizes are randomly scattered in the sample.

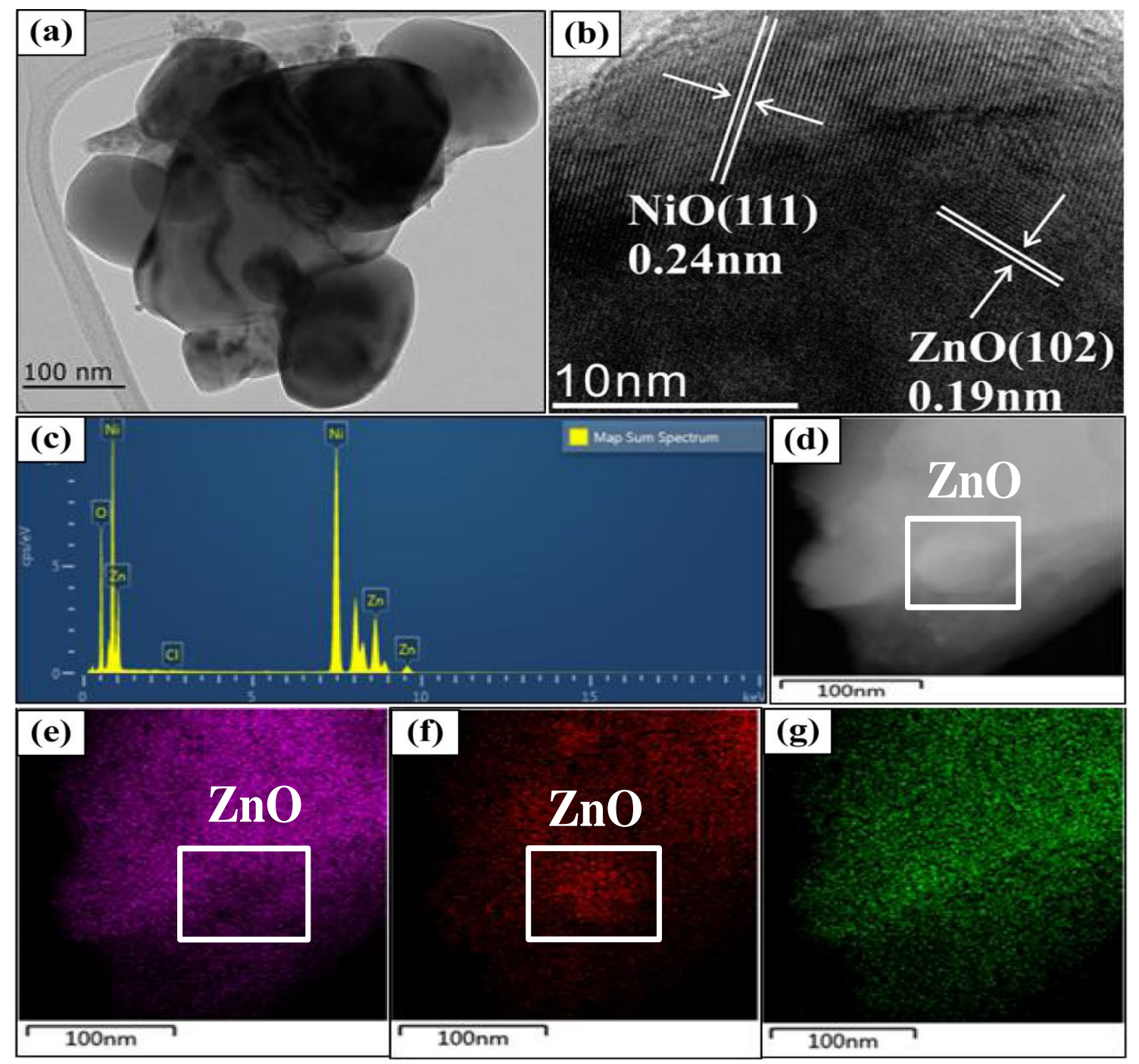

Figure 3. (a) TEM; (b) HRTEM; (c) EDS; (d) TEM-EDS dark-mapping scan; (e-g) TEM-EDS Ni, Zn and O color-mapping scans of $\mathrm{ZnO}-0.425 \mathrm{NiO}$ annealed at $550{ }^{\circ} \mathrm{C}$.

The TEM images demonstrated many nanograins of $\mathrm{ZnO}$ and $\mathrm{NiO}$ in the composite that are either overlapped or in the close contact with each other. This is strong evidence for the development of $\mathrm{p}-\mathrm{n}$ heterojunction in the $\mathrm{ZnO}-0.425 \mathrm{NiO}$. Consequently, the results of the structural properties of $\mathrm{ZnO}-0.425 \mathrm{NiO}$ are inconsistent with the TEM results, suggesting that nanometer $\mathrm{ZnO}$ and $\mathrm{NiO}$ exist separately in the composite, and the $\mathrm{p}-\mathrm{n}$ heterostructures of $\mathrm{ZnO}-\mathrm{NiO}$ are developed at the interface of $\mathrm{ZnO}$ and $\mathrm{NiO}$. Figure $3 \mathrm{~b}$ portrays the HRTEM image of $\mathrm{ZnO}-0.425 \mathrm{NiO}$ composite. The crystal plane spacings of 0.24 and $0.19 \mathrm{~nm}$ are attributed to the crystal plane spacings of $\mathrm{NiO}(111)$ and $\mathrm{ZnO}$ 
(102), respectively. Moreover, the crystal lattice fringe is clear, and the acquired image exhibits a high crystallinity, which is consistent with the obtained XRD results.

Figure $3 \mathrm{c}$ illustrates the EDS spectrum of $\mathrm{ZnO}-0.425 \mathrm{NiO}$ composite and the spectrum reveals the presence of $\mathrm{Zn}, \mathrm{Ni}$ and $\mathrm{O}$ elements in $\mathrm{ZnO}-0.425 \mathrm{NiO}$ sample; there is no $\mathrm{Cl}$ element in the composite, which further confirms the presence of $\mathrm{Ni}$ in the form of $\mathrm{NiO}$. Figure $3 \mathrm{~d}-\mathrm{g}$ shows the EDS dark and color mapping scan images of $\mathrm{ZnO}-0.425 \mathrm{NiO}$, and Figure $3 \mathrm{e}-\mathrm{g}$ shows $\mathrm{Ni}$, $\mathrm{Zn}$, and O elemental color-mapping scans, respectively. Figure $3 \mathrm{~d}-\mathrm{g}$ evidently demonstrates the presence of $\mathrm{O}$, $\mathrm{Zn}$ and $\mathrm{Ni}$ elements in the samples, which confirms the existence of $\mathrm{ZnO}$ nanoparticles among the $\mathrm{NiO}$ nanoparticles. Combined with the XRD patterns and TEM images, the results further indicate that individual $\mathrm{ZnO}$ and $\mathrm{NiO}$ particles are randomly dispersed into the composites. This is another powerful piece of evidence to illustrate the formation of the $\mathrm{p}-\mathrm{n}$ heterojunction, which is additional proof for the gas sensing phenomenon.

XPS spectra of $\mathrm{ZnO}$ and $\mathrm{ZnO}-0.425 \mathrm{NiO}$ composite annealed at $550^{\circ} \mathrm{C}$ were acquired to demonstrate the surface elemental analysis of pristine $\mathrm{ZnO}$ and $\mathrm{ZnO}$ doped with $\mathrm{Ni}$. Figure $4 \mathrm{a}, \mathrm{b}$ delineates the XPS full spectra of $\mathrm{ZnO}$ and $\mathrm{ZnO}-0.425 \mathrm{NiO}$ composite. The $\mathrm{C} 1 \mathrm{~s}$ peak located at $284.6 \mathrm{eV}$ was used to calibrate the XPS spectra. The peaks of $\mathrm{Zn} 2 \mathrm{p}$, Ni 2p and O 1s appear in the XPS spectrum of $\mathrm{ZnO}-0.425 \mathrm{NiO}$ composite, which is consistent with the results obtained from EDS spectra. Figure $4 \mathrm{c}$ shows the high-resolution XPS spectra of $\mathrm{Zn} 2 \mathrm{p}$ state in $\mathrm{ZnO}$ and $\mathrm{ZnO}-0.425 \mathrm{NiO}$. The peaks of $\mathrm{Zn} 2 \mathrm{p}_{3 / 2}$ and $\mathrm{Zn} 2 \mathrm{p}_{1 / 2}$ states for $\mathrm{ZnO}$ are located at 1021.69 and $1044.62 \mathrm{eV}$; the peaks of $\mathrm{Zn} 2 \mathrm{p}_{3 / 2}$ and $\mathrm{Zn} 2 \mathrm{p}_{1 / 2}$ for $\mathrm{ZnO}-0.425 \mathrm{NiO}$ composite are centered at 1022.67 and $1045.6 \mathrm{eV}$; the energy difference between $\mathrm{Zn}$ $2 \mathrm{p}_{3 / 2}$ and $\mathrm{Zn} 2 \mathrm{p}_{1 / 2}$ is about $23 \mathrm{eV}$ both for $\mathrm{ZnO}$ and $\mathrm{ZnO}-0.425 \mathrm{NiO}$ specimens, which are attributed to a normal state of $\mathrm{Zn}^{2+}$ in $\mathrm{ZnO}[50,51]$.

Compared with that of $\mathrm{ZnO}$, the peaks of $\mathrm{Zn} 2 \mathrm{p}_{1 / 2}$ and $\mathrm{Zn} 2 \mathrm{p}_{3 / 2}$ for $\mathrm{ZnO}-0.425 \mathrm{NiO}$ composite are shifted to higher binding energy by $0.98 \mathrm{eV}$, and the reason for this is higher electronegativity of $\mathrm{Ni}(\chi=1.91)$ with respect to $\mathrm{Zn}(\chi=1.65)$ [52-54]. To put it differently, the discrepancy in the electronegativity of $\mathrm{Ni}$ and $\mathrm{Zn}$ resulted in attraction of $\mathrm{Zn}$ electrons by $\mathrm{Ni}$; therefore, the density of outer valence electrons and the screening effect are reduced, which in turn improve the attraction of nuclear and binding energies of the inner electrons [55]. Figure $4 \mathrm{~d}$ delineates the high-resolution XPS spectrum of the Ni $2 \mathrm{p}$ peaks for $\mathrm{ZnO}-0.425 \mathrm{NiO}$ composite. The peaks of $\mathrm{Ni} 2 \mathrm{p}_{3 / 2}$ and its satellite peaks are located at 855.23 and $861.59 \mathrm{eV}$; the peaks of $\mathrm{Ni} 2 \mathrm{p}_{1 / 2}$ and its satellite peaks are centered at 873.22 and $879.58 \mathrm{eV}$, respectively. The energy difference between the $\mathrm{Ni} 2 \mathrm{p}_{3 / 2}$ and $\mathrm{Ni} 2 \mathrm{p}_{1 / 2}$ is about $18 \mathrm{eV}$, which is in good agreement with the previously reported values for $\mathrm{Ni}^{2+}$ in $\mathrm{NiO}$ [56].

The XPS results are consistent with those of XRD and TEM, which prove the presence of $\mathrm{ZnO}$ and $\mathrm{NiO}$ in $\mathrm{ZnO}-0.425 \mathrm{NiO}$. It is evidently known that the reaction of gas on the surface of the sensor results in the electron transfer on the surface which is used to evaluate the gas sensing properties. The size of the particles, the oxygen adsorption and the surface physico-chemical state are three crucial factors for the evaluation of gas sensing performance. Figure 4e,f shows the high-resolution XPS spectra of the O $1 \mathrm{~s}$ state of $\mathrm{ZnO}$ and $\mathrm{ZnO}-0.425 \mathrm{NiO}$ composite. The $\mathrm{O} 1 \mathrm{~s}$ broad peak is separated into three asymmetric peaks centered at $530 \pm 0.2,531 \pm 0.2$ and $532 \pm 0.2 \mathrm{eV}$ for $\mathrm{ZnO}$ and $\mathrm{ZnO}-0.425 \mathrm{NiO}$, which correspond to lattice oxygen, vacancy oxygen and chemisorbed oxygen, respectively [57]. 

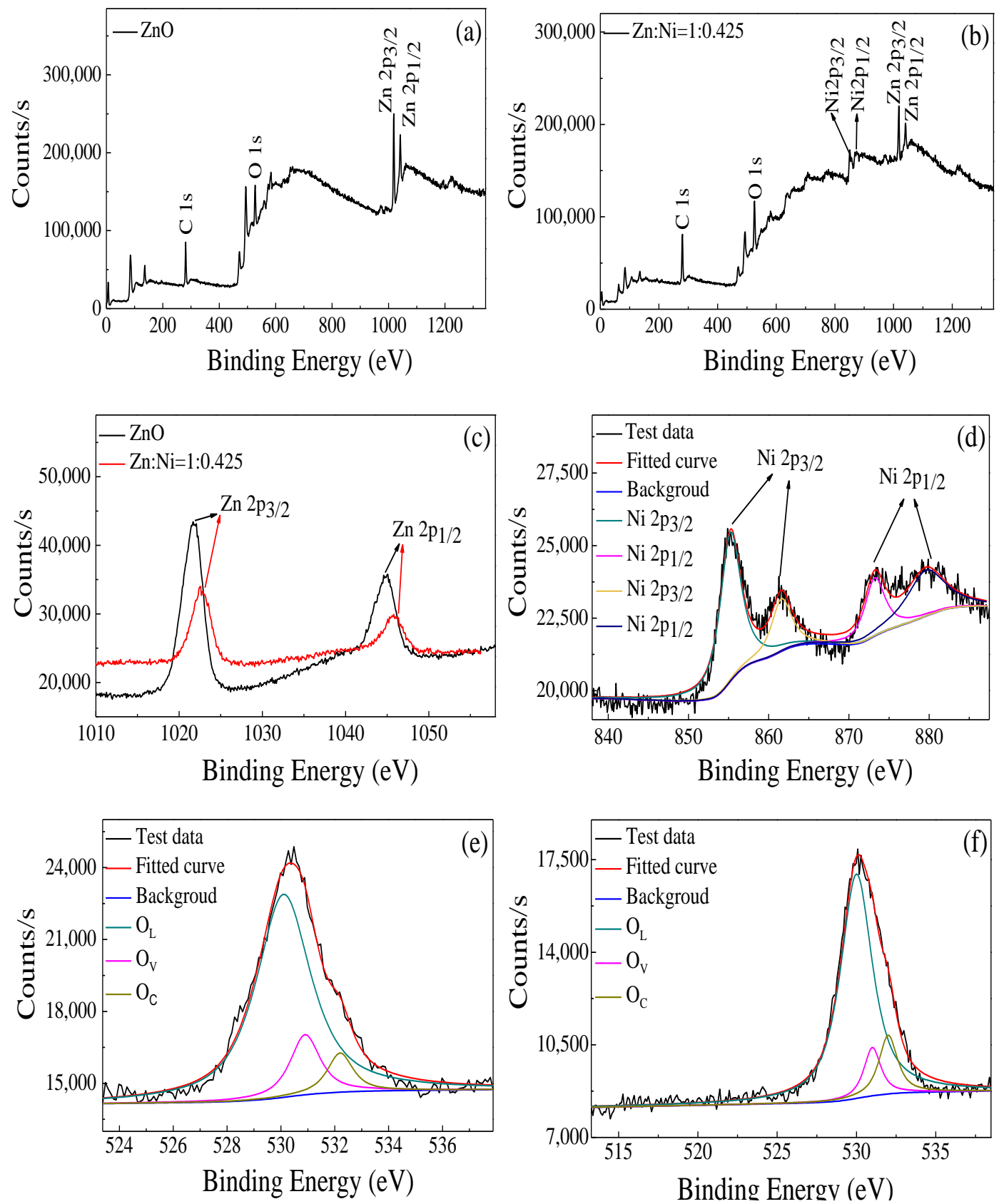

Figure 4. XPS survey spectra of $\mathrm{ZnO}$ and $\mathrm{ZnO}-0.425 \mathrm{NiO}$ annealed at $550{ }^{\circ} \mathrm{C}$ : (a) full spectra of $\mathrm{ZnO}$, (b) full spectra of $\mathrm{ZnO}-0.425 \mathrm{NiO}$, (c) $\mathrm{Zn} 2 \mathrm{p}$ spectra of $\mathrm{ZnO}$ and $\mathrm{ZnO}-0.425 \mathrm{NiO}$, (d) Ni $2 \mathrm{p}$ spectra of $\mathrm{ZnO}-0.425 \mathrm{NiO}$, (e) O 1s spectra of $\mathrm{ZnO}$, (f) O 1 s spectra of $\mathrm{ZnO}-0.425 \mathrm{NiO}$.

The Raman spectra of pristine $\mathrm{ZnO}$ and $\mathrm{ZnO}-0.425 \mathrm{NiO}$ composite were obtained. The peaks in Figure $5 \mathrm{a}$ correspond to the characteristic peaks of $\mathrm{ZnO}$ [58]. The Raman spectrum of $\mathrm{ZnO}-0.425 \mathrm{NiO}$ composite which is shown in Figure $5 \mathrm{~b}$ is different from the spectrum of pristine $\mathrm{ZnO}$, which is shown in Figure 5a; the reason for this change may be the contribution of NiO. Figure $5 c$,d displays the photoluminescence (PL) spectra of pristine $\mathrm{ZnO}$ and $\mathrm{ZnO}-0.425 \mathrm{NiO}$ composite annealed at $550{ }^{\circ} \mathrm{C}$ with excitation wavelength of $325 \mathrm{~nm}$ and carried out at ambient condition. $\mathrm{ZnO}$ and $\mathrm{ZnO}-0.425 \mathrm{NiO}$ composite both exhibit peaks at around 410, 465 and $526 \mathrm{~nm}$ [59]. The emission peak located at about $410 \mathrm{~nm}$ and the peak located at around $465 \mathrm{~nm}$ are attributed to Zinc vacancy (Vzn) and intrinsic defects, respectively. The peak located at about $526 \mathrm{~nm}$ is attributed to the transition between the electrons near the conduction band and the deeply trapped holes [60]. 
(a)

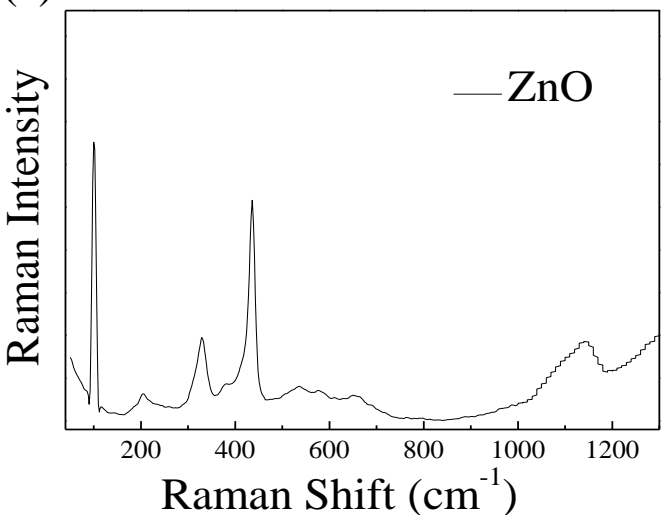

(b)

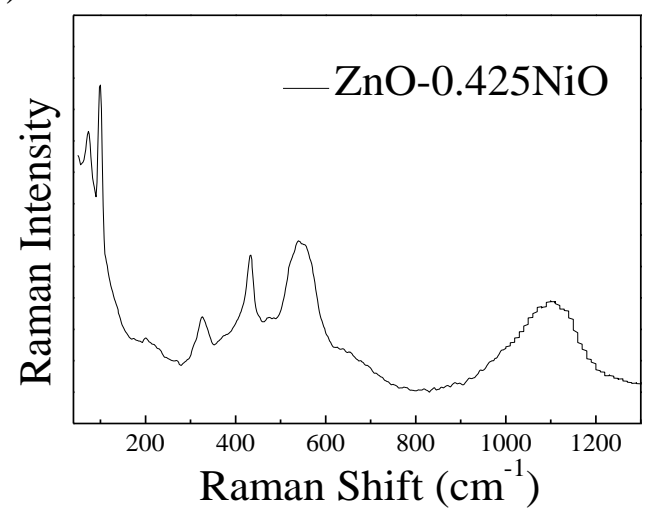

(d)

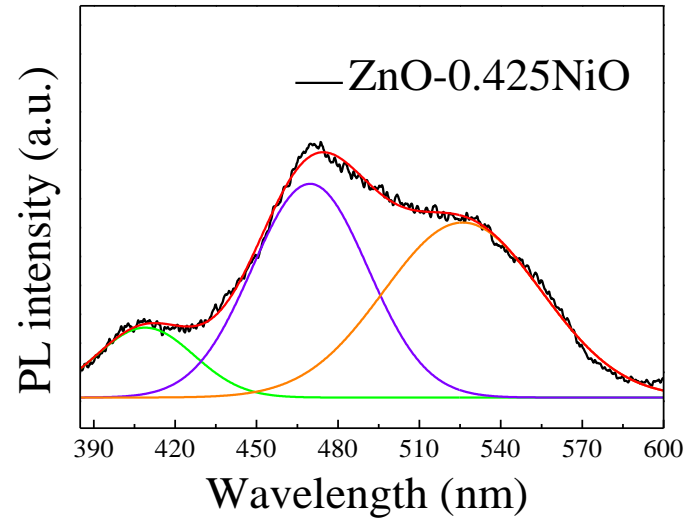

Figure 5. Raman spectra of the (a) pristine $\mathrm{ZnO}$ and (b) $\mathrm{ZnO}-0.425 \mathrm{NiO}$ composite annealed at $550{ }^{\circ} \mathrm{C}$; photoluminescence (PL) spectra of (c) pristine $\mathrm{ZnO}$ and (d) $\mathrm{ZnO}-0.425 \mathrm{NiO}$ composite annealed at $550^{\circ} \mathrm{C}$

\subsection{Sensing Properties of $\mathrm{ZnO}-x \mathrm{NiO}$}

$\mathrm{ZnO}$ and the $\mathrm{ZnO}-x \mathrm{NiO}$ composites annealed at $550{ }^{\circ} \mathrm{C}$ were exposed to $400 \mathrm{ppm} \mathrm{CO}$ and $\mathrm{H}_{2}$ at the operating temperature of $350{ }^{\circ} \mathrm{C}$, and the results are demonstrated in Figure 6a-i. It is commonly known that when an n-type MOS is exposed to reducing gases, the resistance decreases, and the response is positive based on the aforementioned theoretical expression $(\mathrm{R}=\mathrm{Ra} / \mathrm{Rg}-1)$. When p-type MOS is exposed to reducing gases, the resistance increases and the response value is negative. It is evident from Figure 6 that the gas sensing responses to $\mathrm{H}_{2}$ and $\mathrm{CO}$ show an n-type to p-type transformation upon an increase in the value of " $x$ " in $\mathrm{ZnO}-x \mathrm{NiO}$ composite. The gas sensing behavior of $\mathrm{ZnO}-x \mathrm{NiO}$ composite to $\mathrm{CO}$ is transformed from n-type to $\mathrm{p}$-type with the critical " $x$ " value between 0.4 and 0.425 , while the critical " $x$ " value for this transformation to $\mathrm{H}_{2}$ is between 0.425 and 0.429 . As a result, $\mathrm{ZnO}$ and the $\mathrm{ZnO}-x \mathrm{NiO}$ gas sensors with $x<0.425$ show an n-type response to both $\mathrm{CO}$ and $\mathrm{H}_{2}$ gases, whereas $\mathrm{ZnO}-x \mathrm{NiO}$ sensors with $x>0.425$ show a p-type response to these two gases.

However, the sensing results illustrate that the gas sensors based on $\mathrm{ZnO}-0.425 \mathrm{NiO}$ exhibit an n-type response to $\mathrm{H}_{2}$ and an opposite response (p-type) response to $\mathrm{CO}$. Consequently, the sensing behavior (p-type or $\mathrm{n}$-type) of $\mathrm{ZnO}-x \mathrm{NiO}$ gas sensors depends on the composition of $\mathrm{Zn}: \mathrm{Ni}$, and their responses transformed from n-type to $\mathrm{p}$-type with different critical values of " $x$ " in $\mathrm{ZnO}-0.425 \mathrm{NiO}$. Hence, an ultra-high gas sensing discriminability can be obtained for the gas sensors by adjusting the concentration of the composites. Apart from the obtained experimental results, the following explanation of this special gas sensing behavior is proposed. The electrical conductivity of $\mathrm{ZnO}-x \mathrm{NiO}$ with $x<0.425$ is dominated by $\mathrm{ZnO}-\mathrm{ZnO}$ homojunctions, so the gas sensing behavior obeys to the 
depletion layer models. In contrast, the electrical conductivity of $\mathrm{ZnO}-x \mathrm{NiO}$ with $x>0.425$ is dominated by $\mathrm{NiO}-\mathrm{NiO}$ homojunctions, so the gas sensing behavior obeys to the accumulation layer models [61].

(a)

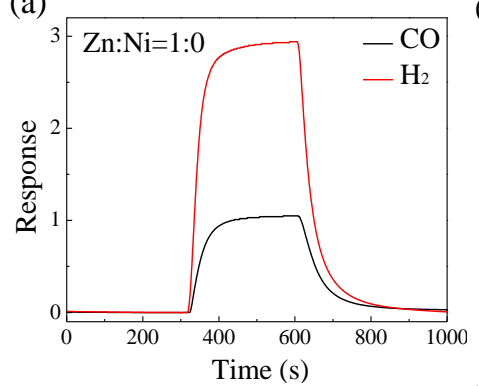

(d)
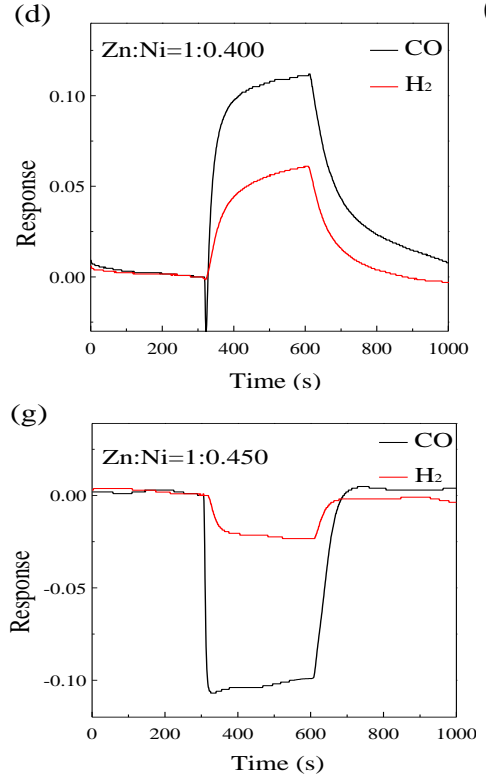

(b)

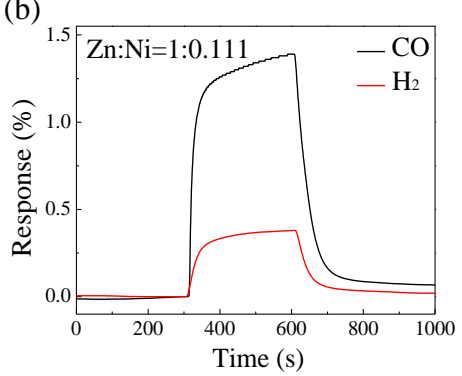

(e)

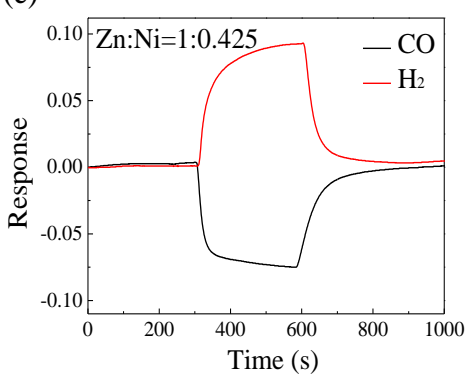

(h)

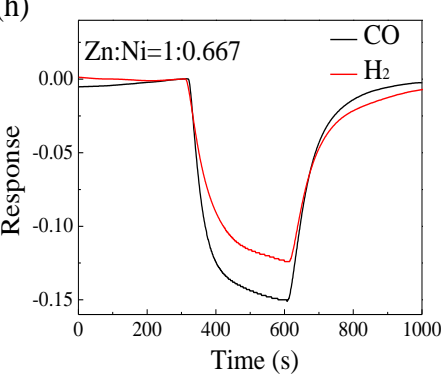

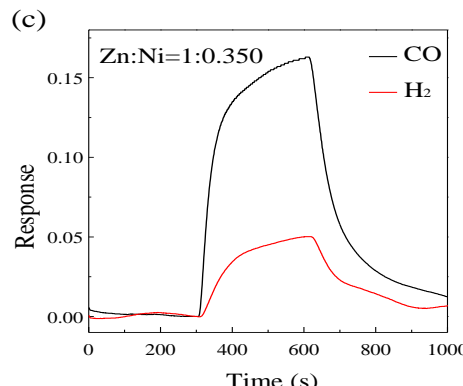

(f)

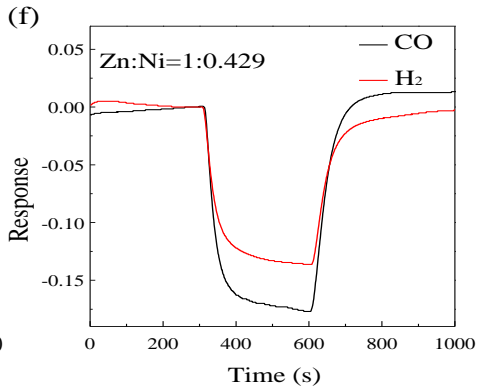

(i)

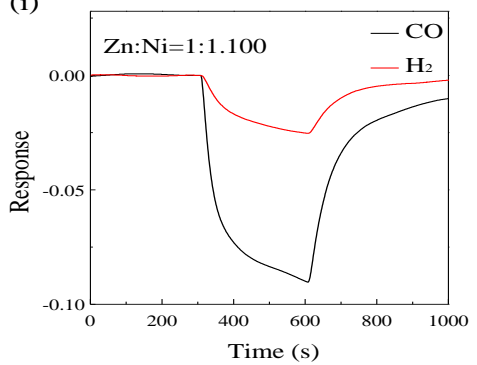

Figure 6. Responses of $\mathrm{ZnO}$ (a) and $\mathrm{ZnO}-x \mathrm{NiO}(x=0.111,0.350,0.400,0.425,0.429,0.450,0.667,1.100)$ (b-i) annealed at $550{ }^{\circ} \mathrm{C}$ to $400 \mathrm{ppm} \mathrm{CO}$ and $\mathrm{H}_{2}$ at the operating temperature of $350{ }^{\circ} \mathrm{C}$.

The electrical conductivity of $\mathrm{ZnO}-0.425 \mathrm{NiO}$ is dominated by $\mathrm{ZnO}-\mathrm{NiO}$ heterojunctions and the connection of $\mathrm{ZnO}$ and $\mathrm{NiO}$ results in the electrons flowing from n-type $\mathrm{ZnO}$ to p-type $\mathrm{NiO}$ to reach the same Fermi energy level. Simultaneously, the heterojunctions form at the interfaces between $\mathrm{ZnO}$ and $\mathrm{NiO}$ and a potential barrier is formed. As soon as the reducing gas is adsorbed on the surface of $\mathrm{ZnO}-0.425 \mathrm{NiO}$, the gas supplies electrons to the surface of the sensor and the electrons transfer back into the conduction band of $\mathrm{ZnO}$ and $\mathrm{NiO}$.

In this case, the potential barrier height of both $\mathrm{ZnO}$ and $\mathrm{NiO}$ decrease and the thickness of electron depletion layer and vacuum accumulation layer becomes thinner; hence, the electron concentration of $\mathrm{ZnO}$ increases and the hole concentration of $\mathrm{NiO}$ decreases. The abnormal sensing behavior of $\mathrm{ZnO}-0.425 \mathrm{NiO}$ can be attributed to various adsorbability of $\mathrm{CO}$ and $\mathrm{H}_{2}$ on the surface of $\mathrm{ZnO}$ and $\mathrm{NiO}$ that result in discrepancy of content changes between the electron concentration increase on the surface of $\mathrm{ZnO}$ and the hole concentration decrease on the surface of $\mathrm{NiO}$. As delineated in Figure 6a, the gas sensing response of pristine $\mathrm{ZnO}$ to $400 \mathrm{ppm} \mathrm{H}_{2}$ is higher than that of $\mathrm{CO}$, which originated from the fact that $\mathrm{H}_{2}$ prefers to adsorb on the surface of $\mathrm{ZnO}$.

When $\mathrm{ZnO}-0.425 \mathrm{NiO}$ is exposed to $\mathrm{H}_{2}$, the increase of the electron concentration in $\mathrm{ZnO}$ is much more than the decrease of hole concentration in $\mathrm{NiO}$, and therefore, the decreased potential barrier height of $\mathrm{ZnO}$ is greater than that of $\mathrm{NiO}$. Thus, in presence of $\mathrm{H}_{2}$, the sensing properties of $\mathrm{ZnO}-0.425 \mathrm{NiO}$ are dominated by the variation of electron concentration and the sensor is electrically conductive and 
in this case the carrier is the electron. Therefore, the gas sensing behavior of $\mathrm{ZnO}-0.425 \mathrm{NiO}$ composite exhibits an n-type response to $\mathrm{H}_{2}$. In contrast, when the $\mathrm{NiO}$ is doped into the $\mathrm{ZnO}$ material, as shown in Figure $6 \mathrm{~b}$, the gas sensing response of $\mathrm{ZnO}-0.111 \mathrm{NiO}$ to $400 \mathrm{ppm} \mathrm{CO}$ is higher than that to $400 \mathrm{ppm}$ $\mathrm{H}_{2}$, which can be explained, as the CO prefers to adsorb on $\mathrm{NiO}$ of $\mathrm{ZnO}-0.111 \mathrm{NiO}$.

To put it differently, when $\mathrm{CO}$ is introduced, the decrease of hole concentration in $\mathrm{NiO}$ is much more than the increase of electron concentration in $\mathrm{ZnO}$, and therefore, the decrease of potential barrier height of $\mathrm{NiO}$ is greater than that of $\mathrm{ZnO}$. When $\mathrm{CO}$ gas exists, the sensing properties of $\mathrm{ZnO}-0.425 \mathrm{NiO}$ are dominated by the variation of hole concentration, and the sensor is hole conductive; and in this case, the carrier is the hole. Therefore, the gas sensing behavior of $\mathrm{ZnO}-0.425 \mathrm{NiO}$ composite illustrates a p-type response to $\mathrm{CO}$. An intriguing gas sensing response to $\mathrm{CO}$ and $\mathrm{H}_{2}$ have been obtained as illustrated in Figure 6. It is evident that the gas sensing response of $\mathrm{ZnO}-0.425 \mathrm{NiO}$ is lower than that of pristine $\mathrm{ZnO}$, and the reason for this presence of more $\mathrm{p}-\mathrm{n}$ heterojunctions in the $\mathrm{ZnO}-0.425 \mathrm{NiO}$ composite and the formation of a potential barrier at the interface of the $\mathrm{ZnO}$ and $\mathrm{NiO}$ in the $\mathrm{ZnO}-0.425 \mathrm{NiO}$, are that this barrier can inhibit the flow of electrons and decrease the gas sensing response.

The sensing reproducibility and stability of $\mathrm{ZnO}-0.425 \mathrm{NiO}$ to $\mathrm{CO}$ and $\mathrm{H}_{2}$ were analyzed. Figure $7 \mathrm{a}, \mathrm{b}$ depicts three cycles of gas sensing response curves of $\mathrm{ZnO}-0.425 \mathrm{NiO}$ annealed at $550{ }^{\circ} \mathrm{C}$ to $400 \mathrm{ppm}$ (a) $\mathrm{CO}$ and (b) $\mathrm{H}_{2}$ at the operating temperature of $350{ }^{\circ} \mathrm{C}$, respectively. The results indicate the reproducibility and stability of such behavior. It is worth noting that the process conditions for reproducibility of such results requires a high accuracy, and when any of the factors affecting gas sensing behavior (p-type or n-type), including concentration of sensing materials, operating temperature, etc., changes, then the critical value $x$ for the $\mathrm{p}-\mathrm{n}$ transformation might be changed. In addition, the heating mode of the sensor which is heating the substrate [62] or the whole gas sensing detection chamber [63] may also affect the gas sensing behavior.

(a)

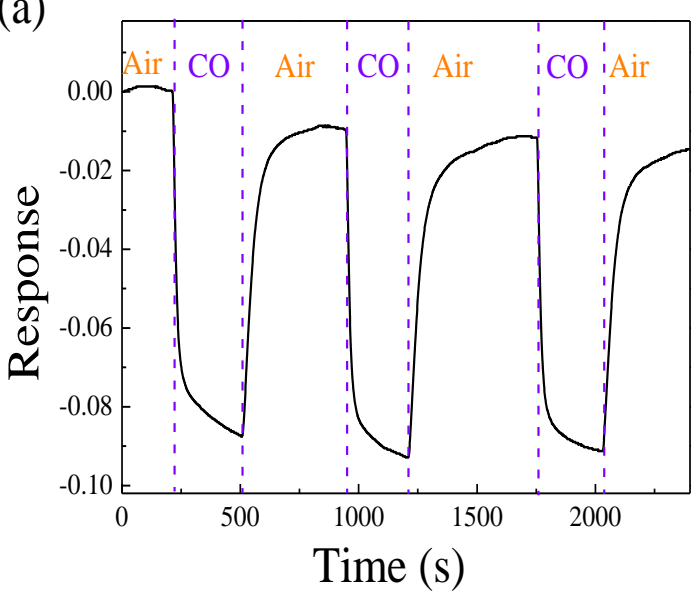

(b)

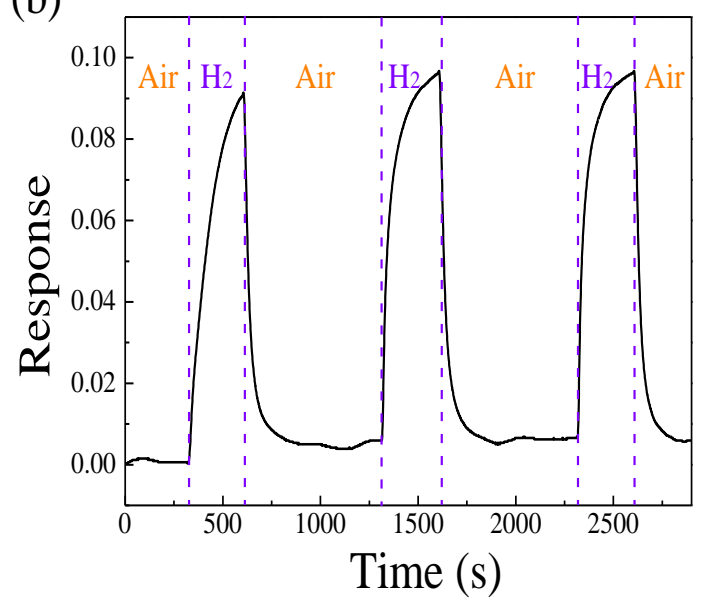

Figure 7. Three cycles of dynamic gas sensing response curve of $\mathrm{ZnO}-0.425 \mathrm{NiO}$ annealed at $550{ }^{\circ} \mathrm{C}$ to $400 \mathrm{ppm} \mathrm{CO}(\mathbf{a})$ and $\mathrm{H}_{2}(\mathbf{b})$ at $350{ }^{\circ} \mathrm{C}$.

As shown in Figure $8 \mathrm{a}-\mathrm{c}, \mathrm{ZnO}-0.425 \mathrm{NiO}$ gas sensors annealed at 500,550 and $600{ }^{\circ} \mathrm{C}$ were exposed to $400 \mathrm{ppm} \mathrm{CO}$ and $\mathrm{H}_{2}$ at 300,350 and $400{ }^{\circ} \mathrm{C}$ operating temperatures, respectively. Among these different cases, the gas sensor based on $\mathrm{ZnO}-0.425 \mathrm{NiO}$ as the sensing material and annealed at $500{ }^{\circ} \mathrm{C}$ delineates a p-type response to both $\mathrm{CO}$ and $\mathrm{H}_{2}$, while the same gas sensor annealed at $600{ }^{\circ} \mathrm{C}$ demonstrates an n-type response to these two gases.

Surprisingly, the gas sensor based on $\mathrm{ZnO}-0.425 \mathrm{NiO}$ composite and annealed at $550{ }^{\circ} \mathrm{C}$ showed an n-type response to $\mathrm{CO}$ and $\mathrm{H}_{2}$ at $300{ }^{\circ} \mathrm{C}$ and showed a p-type response to $\mathrm{CO}$ and $\mathrm{H}_{2}$ at $400{ }^{\circ} \mathrm{C}$, while it showed an n-type response to $\mathrm{H}_{2}$ and a p-type response to $\mathrm{CO}$ at $350^{\circ} \mathrm{C}$ (Figure $8 \mathrm{~b}$ ). Therefore, in addition to the molar ratio of $\mathrm{Zn}: \mathrm{Ni}$ in the composite materials, the heat treatment including annealing 
and operating temperatures have fundamental roles in the response ( $\mathrm{p}$ or $\mathrm{n}$-type) of gas sensors. Therefore, the sensing behavior of $\mathrm{ZnO}-x \mathrm{NiO}$ gas sensors is influenced by factors such as the contents of sensing materials and their compositions, and calcination and working temperatures. As a result, it was found that $\mathrm{ZnO}-0.425 \mathrm{NiO}$ sensor annealed at $550{ }^{\circ} \mathrm{C}$ showed opposite gas sensing behavior to $\mathrm{CO}$ and $\mathrm{H}_{2}$ at $350{ }^{\circ} \mathrm{C}$ operating temperature.

(a)

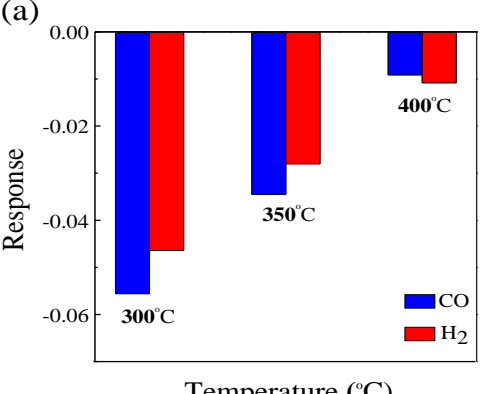

(b)

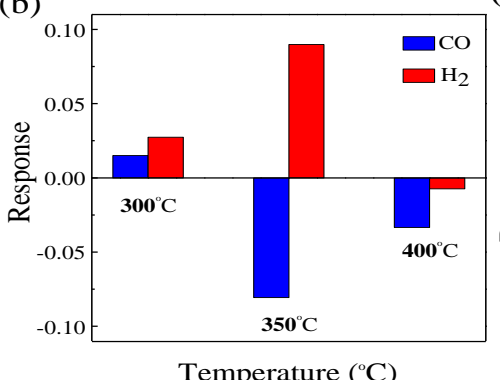

(c)

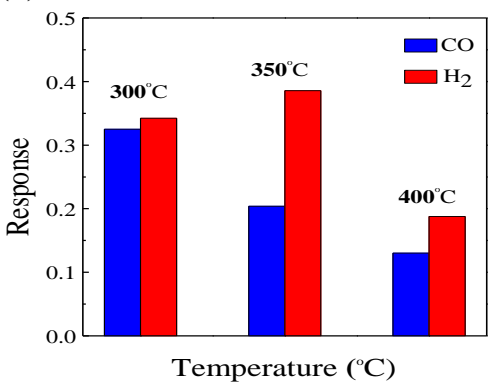

Figure 8. Response value of $\mathrm{ZnO}-0.425 \mathrm{NiO}$ annealed at (a) $500{ }^{\circ} \mathrm{C}$, (b) $550{ }^{\circ} \mathrm{C}$, (c) $600{ }^{\circ} \mathrm{C}$ to $400 \mathrm{ppm}$ $\mathrm{CO}$ at different operating temperatures.

\section{Conclusions}

$\mathrm{ZnO}-x \mathrm{NiO}$ composites were successfully prepared using simple sol-gel method. They were annealed at different temperatures and used as the sensing materials for the fabrication of gas sensors. The sensitivity results elucidate that the response of $\mathrm{ZnO}-0.425 \mathrm{NiO}$ could be of p-type or n-type, depending on factors such as the molar ratio of $\mathrm{Zn} / \mathrm{Ni}$ and heat treatment, including post-annealing and operating temperatures. The obtained gas sensing results evidently illustrate that $\mathrm{ZnO}-0.425 \mathrm{NiO}$ annealed at $550{ }^{\circ} \mathrm{C}$ and tested at $350{ }^{\circ} \mathrm{C}$ exhibited a p-type response to $\mathrm{CO}$ but the opposite response (n-type) to $\mathrm{H}_{2}$, which indicates the modulation of molar ratio of $\mathrm{Zn} / \mathrm{Ni}$ in the $\mathrm{p}-\mathrm{n}$ composites $(\mathrm{ZnO}-x \mathrm{NiO})$ could be an effective way to improve the poor discriminability of this type of gas sensor to the homogeneous gases. The explanation of the special gas sensing behavior of $\mathrm{ZnO}-0.425 \mathrm{NiO}$ to $\mathrm{CO}$ and $\mathrm{H}_{2}$ is proposed based on band theory and the observed experimental observations including XRD, HRTEM and XPS. This paper provides an idea for designing $\mathrm{p}-\mathrm{n}$ composites to improve the gas sensing discriminability of target gases.

Author Contributions: Conceptualization, J.L. and X.-T.Y.; methodology, X.-T.Y. and D.D.; software, W.-D.Z.; validation, Q.W. and X.-T.Y.; formal analysis, W.-D.Z.; investigation, W.-D.Z; resources, Q.W., J.L. and X.-T.Y.; data curation, W.-D.Z.; writing-original draft preparation, W.-D.Z.; writing—review and editing, W.-D.Z. and D.D.; visualization, W.-D.Z.; supervision, Q.W.; project administration, J.L.; funding acquisition, Q.W., J.L. and X.-T.Y. All authors have read and agreed to the published version of the manuscript.

Funding: The financial support was provided by the National Natural Science Foundation of China (grant numbers 51974157, 51874169, 51774180 and 51634004) and the Basic Scientific Research Project of colleges and universities in Liaoning Province (grant number 2019LNJC15).

Conflicts of Interest: The authors declare no conflict of interest.

\section{References}

1. Koo, W.-T.; Qiao, S.; Ogata, A.F.; Jha, G.; Jang, J.-S.; Chen, V.T.; Kim, I.-T.; Penner, R.M. Accelerating Palladium Nanowire $\mathrm{H}_{2}$ Sensors Using Engineered Nanofifiltration. ACS Nano 2017, 11, 9276-9285. [CrossRef] [PubMed]

2. Huang, H.; Gong, H.; Chow, C.L.; Guo, J.; White, T.J.; Tse, M.S.; Tan, O.K. Low-Temperature Growth of $\mathrm{SnO}_{2}$ Nanorod Arrays and Tunable n-p-n Sensing Response of a $\mathrm{ZnO} / \mathrm{SnO}_{2}$ Heterojunction for Exclusive Hydrogen Sensors. Adv. Funct. Mater. 2011, 21, 2680-2686. [CrossRef]

3. Zhou, Q.; Xu, L.; Umar, A.; Chen, W.; Kumar, R. Pt nanoparticles decorated $\mathrm{SnO}_{2}$ nanoneedles for effificient CO gas sensing applications. Sens. Actuators B 2018, 256, 656-664. [CrossRef] 
4. Barbosa, M.S.; Suman, P.H.; Kim, J.J.; Tuller, H.L.; Varela, J.A.; Orlandi, M.O. Gas sensor properties of Agand Pd-decorated $\mathrm{SnO}$ micro-disks to $\mathrm{NO}_{2}, \mathrm{H}_{2}$ and $\mathrm{CO}$ : Catalyst enhanced sensor response and selectivity. Sens. Actuators B 2017, 239, 253-261. [CrossRef]

5. Yang, S.; Wang, Z.; Hu, Y.; Luo, X.; Lei, J.; Zhou, D.; Fei, L.; Wang, Y.; Gu, H. Highly Responsive Room-Temperature Hydrogen Sensing of $\alpha-\mathrm{MoO}_{3}$, Nanoribbon Membranes. ACS Appl. Mater. Interfaces 2015, 7, 9247-9253. [CrossRef] [PubMed]

6. Zou, X.; Wang, J.; Liu, X.; Wang, C.; Jiang, Y.; Wang, Y.; Xiao, X.; Ho, J.C.; Li, J.; Fang, Y.; et al. Rational Design of Sub-Parts per Million Specifific Gas Sensors Array Based on Metal Nanoparticles Decorated Nanowire Enhancement Mode Transistors. Nano Lett. 2013, 13, 3287-3292. [CrossRef]

7. Yin, X.T.; Tao, L. Fabrication and gas sensing properties of Au-loaded $\mathrm{SnO}_{2}$ composite nanoparticles for low concentration hydrogen. J. Alloys Compd. 2017, 727, 254-259. [CrossRef]

8. Han, D.M.; Zhai, L.L.; Gu, F.B.; Wang, Z.H. Highly sensitive $\mathrm{NO}_{2}$ gas sensor of ppb-level detection based on $\mathrm{In}_{2} \mathrm{O}_{3}$ nanobricks at lowtemperature. Sens. Actuators B 2018, 262, 655-663. [CrossRef]

9. Yin, X.T.; Guo, X.M. Selectivity and sensitivity of Pd-loaded and Fe-doped $\mathrm{SnO}_{2}$ sensor for CO detection. Sens. Actuators B 2014, 200, 213-218. [CrossRef]

10. Li, R.; Zhou, Y.; Sun, M.; Gong, Z.; Guo, Y.; Yin, X.; Wu, F.; Ding, W. Gas sensing selectivity of oxygen-regulated $\mathrm{SnO}_{2}$ films with different microstructure and texture. J. Mater. Sci. Technol. 2019, 35, 2232-2237. [CrossRef]

11. Kaur, M.; Dadhich, B.K.; Singh, R.; Bagwaiya, T.; Bhattacharya, S.; Debnath, A.K.; Muthe, K.P.; Gadkari, S.C. $\mathrm{RF}$ sputtered $\mathrm{SnO}_{2}$ : $\mathrm{NiO}$ thin films as sub-ppm $\mathrm{H}_{2} \mathrm{~S}$ sensor operable at room temperature. Sens. Actuators $B$ 2016, 242, 389-403. [CrossRef]

12. Wu, Z.; Li, Z.; Li, H.; Sun, M.; Han, S.; Cai, C.; Shen, W.; Fu, Y. Ultrafast Response/Recovery and High Selectivity of the $\mathrm{H}_{2} \mathrm{~S}$ Gas Sensor Based on $\alpha-\mathrm{Fe}_{2} \mathrm{O}_{3}$ Nano-Ellipsoids from One-Step Hydrothermal Synthesis. ACS Appl. Mater. Interfaces 2019, 11, 12761-12769. [CrossRef] [PubMed]

13. Zhang, J.; Lu, H.; Yan, C.; Yang, Z.; Zhu, G.; Gao, J.; Yin, F.; Wang, C. Fabrication of conductive graphene oxide- $\mathrm{WO}_{3}$ composite nanofibers by electrospinning and their enhanced acetone gas sensing properties. Sens. Actuators B 2018, 264, 128-138. [CrossRef]

14. Zhang, D.; Jiang, C.; Wu, J. Layer-by-layer assembled $\mathrm{In}_{2} \mathrm{O}_{3}$ nanocubes/flower-like $\mathrm{MoS}_{2}$ nanofilm for room temperature formaldehyde sensing. Sens. Actuators B 2018, 273, 176-184. [CrossRef]

15. Abbasi, S.; Hasanpour, M.; Ahmadpoor, F.; Sillanpää, M.; Dastan, D.; Achour, A. Application of the statistical analysis methodology for photodegradation of methyl orange using a new nanocomposite contining modified $\mathrm{TiO}_{2}$ semiconductor with $\mathrm{SnO}_{2}$. Int. J. Environ. Anal. Chem. 2019. [CrossRef]

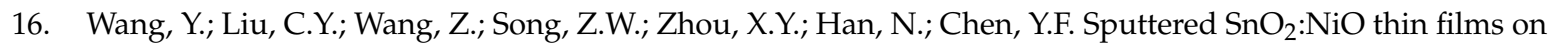
self-assembled Au nanoparticle arrays for MEMS compatible $\mathrm{NO}_{2}$ gas sensors. Sens. Actuators B 2019, 278, 28-38. [CrossRef]

17. Jafari, A.; Alam, M.; Dastan, D.; Ziakhodadadian, S.; Shi, Z.; Garmestani, H.; Weidenbach, A.; Ţălu, Ş. Statistical, morphological, and corrosion behavior of PECVD derived cobalt oxide thin flms. J. Mater. Sci. Mater. Electron. 2019, 30, 21185-21198.

18. Kwak, C.-H.; Woo, H.-S.; Lee, J.-H. Selective trimethylamine sensors using $\mathrm{Cr}_{2} \mathrm{O}_{3}$-decorated $\mathrm{SnO}_{2} \mathrm{Nanowires}$ Sens. Actuators B 2014, 204, 231-238. [CrossRef]

19. Jafari, A.; Tahani, K.; Dastan, D.; Asgary, S.; Shi, Z.; Yin, X.-T.; Zhou, W.-D.; Garmestani, H.; Ţălu, Ş. Ion Implantation of Copper Oxide Thin Films; Statistical and Experimental Results. Surf. Interfaces 2020, 18, 100463. [CrossRef]

20. $\mathrm{Hu}$, Y.; Li, L.; Zhang, L.; Lv, Y. Dielectric barrier discharge plasma-assisted fabrication of g- $\mathrm{C}_{3} \mathrm{~N}_{4}-\mathrm{Mn}_{3} \mathrm{O}_{4}$ composite for high-performance cataluminescence $\mathrm{H}_{2} \mathrm{~S}$ gas sensor. Sens. Actuators B 2017, 239, 1177-1184. [CrossRef]

21. Han, F.; Song, Z.; Nawaz, M.H.; Dai, M.; Han, D.; Han, L.; Fan, Y.; Xu, J.; Han, D. MoS2/ZnO-HeterostructuresBased Label-Free, Visible-Light-Excited Photoelectrochemical Sensor for Sensitive and Selective Determination of Synthetic Antioxidant Propyl Gallate. Anal. Chem. 2019, 91, 10657-10662. [CrossRef]

22. Rai, P.; Kwak, W.-K.; Yu, Y.-T. Solvothermal Synthesis of ZnO Nanostructures and Their Morphology-Dependent Gas-Sensing Properties. ACS Appl. Mater. Interfaces 2013, 5, 3026-3032. [CrossRef]

23. Woo, H.-S.; Kwak, C.-H.; Chung, J.-H.; Lee, J.-H. Co-Doped Branched ZnO Nanowires for Ultra selective and Sensitive Detection of Xylene. ACS Appl. Mater. Interfaces 2014, 6, 22553-22560. [CrossRef]

24. Zhou, X.; Zou, Y.; Ma, J.; Cheng, X.; Li, Y.; Deng, Y.; Zhao, D. Cementing Mesoporous ZnO with Silica for Controllable and Switchable Gas Sensing Selectivity. Chem. Mater. 2019, 31, 8112-8120. [CrossRef] 
25. Ghosh, A.; Zhang, C.; Zhang, H.; Shi, S. $\mathrm{CO}_{2}$ Sensing Behavior of Calcium-Doped ZnO Thin Film: A Study To Address the Cross-Sensitivity of $\mathrm{CO}_{2}$ in $\mathrm{H}_{2}$ and $\mathrm{CO}$ Environment. Langmuir 2019, 35, 10267-10275. [CrossRef] [PubMed]

26. Moon, W.J.; Yu, J.H.; Choi, G.M. The $\mathrm{CO}$ and $\mathrm{H}_{2}$ gas selectivity of $\mathrm{CuO}$-doped $\mathrm{SnO}_{2}-\mathrm{ZnO}$ composite gas sensor. Sens. Actuators B 2002, 87, 464-470. [CrossRef]

27. Drobek, M.; Kim, J.-H.; Bechelany, M.; Vallicari, C.; Leroy, E.; Julbe, A.; Kim, S.S. Design and Fabrication of Highly Selective $\mathrm{H}_{2}$ Sensors Based on SIM-1 Nanomembrane-Coated ZnO Nanowires. Sens. Actuators $B$ 2018, 264, 410-418. [CrossRef]

28. Fan, F.; Zhang, J.; Li, J.; Zhang, N.; Hong, R.; Deng, X.; Tang, P.; Li, D. Hydrogen sensing properties of Pt-Au bimetallic nanoparticles loaded on ZnO nanorods. Sens. Actuators B 2017, 241, 895-903. [CrossRef]

29. Majhi, S.M.; Rai, P.; Yu, Y.-T. Facile Approach to Synthesize Au@ZnO Core-Shell Nanoparticles and Their Application for Highly Sensitive and Selective Gas Sensors. ACS Appl. Mater. Interfaces 2015, 7, 9462-9468. [CrossRef]

30. Yin, X.-T.; Zhou, W.-D.; Li, J.; Lv, P.; Wang, Q.; Wang, D.; Wu, F.-Y.; Dastan, D.; Garmestani, H.; Shi, Z.; et al. Tin dioxide nanoparticles with high sensitivity and selectivity for gas sensors at sub-ppm level of hydrogen gas detection. J. Mater. Sci. Mater. Electron. 2019, 30,14687-14694. [CrossRef]

31. Guo, L.; Chen, F.; Xie, N.; Kou, X.; Wang, C.; Sun, Y.; Liu, F.; Liang, X.; Gao, Y.; Yan, X.; et al. Ultra-sensitive sensing platform based on Pt- $\mathrm{ZnO}-\mathrm{In}_{2} \mathrm{O}_{3}$ nanofifibers for detection of acetone. Sens. Actuators B 2018, 272, 185-194. [CrossRef]

32. Yin, X.-T.; Zhou, W.-D.; Li, J.; Wang, Q.; Wu, F.-Y.; Dastan, D.; Wang, D.; Garmestani, H.; Wang, X.-M.; Talu, S. A highly sensitivity and selectivity $\mathrm{Pt}-\mathrm{SnO}_{2}$ nanoparticles for sensing applications at extremely low level hydrogen gas detection. J. Alloys Compd. 2019, 805, 229-236. [CrossRef]

33. Zhu, L.; Zeng, W. Room-temperature gas sensing of ZnO-based gas sensor: A review. Sens. Actuators A 2017, 267, 242-261. [CrossRef]

34. Yin, X.-T.; Lv, P.; Li, J.; Jafari, A.; Wu, F.-Y.; Wang, Q.; Dastan, D.; Shi, Z.; Yu, S.; Garmestani, H. Nanostructured Tungsten Trioxide Prepared at Various Growth Temperatures for Sensing Applications. J. Alloys Compd. 2020, 825,154105 . [CrossRef]

35. Joy, N.A.; Nandasiri, M.I.; Rogers, P.H.; Jiang, W.; Varga, T.; Kuchibhatla, S.V.N.T.; Thevuthasan, S.; Carpenter, M.A. Selective Plasmonic Gas Sensing: $\mathrm{H}_{2}, \mathrm{NO}_{2}$, and $\mathrm{CO}$ Spectral Discrimination by a Single Au- $\mathrm{CeO}_{2}$ Nanocomposite Film. Anal. Chem. 2012, 84, 5025-5034. [CrossRef]

36. Sun, G.-J.; Lee, J.K.; Choi, S.; Lee, W.I.; Kim, H.W.; Lee, C. Selective Oxidizing Gas Sensing and Dominant Sensing Mechanism of n-CaO-Decorated n-ZnO Nanorod Sensors. ACS Appl. Mater. Interfaces 2017, 9, 9975-9985. [CrossRef]

37. Katoch, A.; Kim, J.-H.; Kwon, Y.J.; Kim, H.W.; Kim, S.S. Bifunctional Sensing Mechanism of $\mathrm{SnO}_{2}-\mathrm{ZnO}$ Composite Nanofibers for Drastically Enhancing the Sensing Behavior in $\mathrm{H}_{2}$ Gas. ACS Appl. Mater. Interfaces 2015, 7, 11351-11358. [CrossRef]

38. Katoch, A.; Abideen, Z.U.; Kim, H.W.; Kim, S.S. Grain-Size-Tuned Highly $\mathrm{H}_{2}$-Selective Chemiresistive Sensors Based on $\mathrm{ZnO}-S n O_{2}$ Composite Nanofifibers. ACS Appl. Mater. Interfaces 2016, 8, 2486-2494. [CrossRef]

39. Zhang, Z.; Xu, M.; Liu, L.; Ruan, X.; Yan, J.; Zhao, W.; Yun, J.; Wang, Y.; Qin, S.; Zhang, T. Novel SnO $@_{2} Z_{n O}$ hierarchical nanostructures for highly sensitive and selective $\mathrm{NO}_{2}$ gas sensing. Sens. Actuators B 2018, 257, 714-727. [CrossRef]

40. Lupan, O.; Postica, V.; Grottrup, J.; Mishra, A.K.; de Leeuw, N.H.; Carreira, J.F.C.; Rodrigues, J.; Sedrine, N.B.; Correia, M.R.; Monteiro, T.; et al. Hybridization of Zinc Oxide Tetrapods for Selective Gas Sensing Applications. ACS Appl. Mater. Interfaces 2017, 9, 4084-4099. [CrossRef]

41. Kim, J.-H.; Lee, J.-H.; Mirzaei, A.; Kim, H.W.; Kim, S.S. Optimization and gas sensing mechanism of n-SnO $-\mathrm{S}_{2}-\mathrm{Co}_{3} \mathrm{O}_{4}$ composite nanofibers. Sens. Actuators B 2017, 248, 500-511. [CrossRef]

42. Yin, X.-T.; Dastan, D.; Wu, F.-Y.; Li, J. Facile Synthesis of $\mathrm{SnO}_{2} / \mathrm{LaFeO}_{3}-\mathrm{XNX}$ Composite: Photocatalytic Activity and Gas Sensing Performance. Nanomaterials 2019, 9, 1163. [CrossRef] [PubMed]

43. Kaur, N.; Zappa, D.; Ferroni, M.; Poli, N.; Campanini, M.; Negrea, R.; Comini, E. Branch-like NiO/ZnO heterostructures for VOC sensing. Sens. Actuators B 2018, 262, 477-485. [CrossRef]

44. Xu, Q.; Ju, D.; Zhang, Z.; Yuan, S.; Zhang, J.; Xu, H.; Cao, B. Near room-temperature triethylamine sensor constructed with $\mathrm{CuO} / \mathrm{ZnO} \mathrm{P}-\mathrm{N}$ heterostructural nanorods directly on flflat electrode. Sens. Actuators B 2016, 225, 16-23. [CrossRef] 
45. Sang, D.; Wang, Q.; Wang, Q.; Zhang, D.; Hu, H.; Wang, W.; Zhang, B.; Fan, Q.; Li, H. Improved electrical transport properties of an $\mathrm{n}-\mathrm{ZnO}$ nanowire/p-diamond heterojunction. R. Soc. Chem. 2018, 8, 28804-28809. [CrossRef]

46. Nakate, U.T.; Ahmad, R.; Patil, P.; Wang, Y.; Bhat, K.S.; Mahmoudi, T.; Yu, Y.T.; Suh, E.-K.; Hahn, Y.B. Improved selectivity and low concentration hydrogen gas sensor application of Pd sensitized heterojunction n-ZnO/p-NiO nanostructures. J. Alloys Compd. 2019, 797, 456-464. [CrossRef]

47. Lee, J.-H.; Kim, J.-Y.; Mirzaei, A.; Kim, H.W.; Kim, S.S. Signifificant Enhancement of Hydrogen-Sensing Properties of ZnO Nanofifibers through NiO Loading. Nanomaterials 2018, 8, 902. [CrossRef]

48. Dastan, D. Nanostructured Anatase Titania Thin Films Prepared by Sol-Gel Dip Coating Technique. J. At. Mol. Condens. Nano Phys. 2015, 2, 109-114.

49. Dastan, D. Effect of preparation methods on the properties of titania nanoparticles: Solvothermal versus sol-gel. Appl. Phys. A 2017, 123, 699. [CrossRef]

50. Wang, L.; Kang, Y.; Wang, Y.; Zhu, B.; Zhang, S.; Huang, W.; Wang, S. CuO nanoparticle decorated ZnO nanorod sensor for low-temperature $\mathrm{H}_{2} \mathrm{~S}$ detection. Mater. Sci. Eng. C 2012, 32, 2079-2085. [CrossRef]

51. Liu, X.; Du, B.; Sun, Y.; Yu, M.; Yin, Y.; Tang, W.; Chen, C.; Sun, L.; Yang, B.; Ashfold, M.N.; et al. Sensitive room temperature photoluminescence-based sensing of $\mathrm{H}_{2} \mathrm{~S}$ with novel CuO-ZnO nanorods. ACS Appl. Mater. Interfaces 2016, 8, 16379-16385. [CrossRef] [PubMed]

52. Zhang, Z.; Shao, C.; Li, X.; Wang, C.; Zhang, M.; Liu, A.Y. Electrospun Nanofibers of p-Type NiO/n-Type ZnO Heterojunctions with Enhanced Photocatalytic Activity. ACS Appl. Mater. Interfaces 2010, 2, 2915-2923. [CrossRef] [PubMed]

53. Tan, C.H.; Tan, S.T.; Lee, H.B.; Ginting, R.T.; Oleiwi, H.F.; Yap, C.C.; Jumali, M.H.H.; Yahay, M. Automated room temperature optical absorbance $\mathrm{CO}$ sensor based on In-doped $\mathrm{ZnO}$ nanorod. Sens. Actuators B 2017, 248, 140-152. [CrossRef]

54. Moulder, J.F.; Stickle, W.F.; Sobol, P.E.; Bomben, K.D. Handbook of X-Ray Photoelectron Spectroscopy; Chastain, J., Ed.; Perkin-Elmer Corp.: New York, NY, USA, 1992.

55. Wang, X.; Gao, M. Porous $\mathrm{Co}_{3} \mathrm{O}_{4} / \mathrm{SnO}_{2}$ quantum dots (QDs) heterostructure with abundant oxygen vacancies and $\mathrm{Co}^{2+}$ ions for highly efficient gas sensing and oxygen evolution Reaction. Nanoscale 2018, 25, 12045-12053. [CrossRef]

56. Zhang, L.; He, J.; Jiao, W. Synthesis and gas sensing performance of $\mathrm{NiO}$ decorated $\mathrm{SnO}_{2}$ vertical standing nanotubes composite thin films. Sens. Actuators B 2019, 281, 326-334. [CrossRef]

57. Gao, H.; Yu, Q.; Zhang, S.; Wang, T.; Sun, P.; Lu, H.; Liu, F.; Yan, X.; Liu, F.; Liang, X.; et al. Nanosheet-assembled $\mathrm{NiO}$ microspheres modified by $\mathrm{Sn}^{2+}$ ions isovalent interstitial doping for xylene gas sensors. Sens. Actuators B 2018, 269, 210-222. [CrossRef]

58. Elger, A.-K.; Hess, C. Application of Raman Spectroscopy to Working Gas Sensors: From In Situ to Operando Studies. Sensors 2019, 19, 5075. [CrossRef]

59. Do, T.A.T.; Giang, H.T.; van Huong, D.; Ngan, P.Q.; Thai, G.H.; Thu, D.T.; Lam, T.D. Correlation between photoluminescence spectra with gas sensing and photocatalytic activities in hierarchical $\mathrm{ZnO}$ nanostructures. RSC Adv. 2017, 7, 9826-9832.

60. Lokesh, K.; Kavitha, G.; Manikandan, E.; Mani, G.K.; Kaviyarasu, K.; Rayappan, J.B.B.; Ladchumananandasivam, R.; Aanand, J.S.; Jayachandran, M.; Maaza, M. Effective Ammonia Detection Using n-ZnO/p-NiO Heterostructured Nanofibers. IEEE Sens. J. 2016, 16, 2477-2483. [CrossRef]

61. Barsan, N.; Hübner, M.; Weimar, U. Conduction mechanisms in $\mathrm{SnO}_{2}$ based polycrystalline thick film gas sensors exposed to $\mathrm{CO}$ and $\mathrm{H}_{2}$ in different oxygen backgrounds. Sens. Actuators B 2011, 157, 510-517. [CrossRef]

62. Xu, L.; Zheng, R.; Liu, S.; Song, J.; Chen, J.; Dong, B.; Song, H. NiO@ZnO Heterostructured Nanotubes: Coelectrospinning Fabrication, Characterization, and Highly Enhanced Gas Sensing Properties. Inorg. Chem. 2012, 51, 7733-7740. [CrossRef] [PubMed]

63. Liu, W.; Gu, D.; Li, X. Ultrasensitive $\mathrm{NO}_{2}$ Detection Utilizing Mesoporous ZnSe/ZnO Heterojunction-Based Chemiresistive-Type Sensors. ACS Appl. Mater. Interfaces 2019, 11, 29029-29040. [CrossRef] [PubMed]

(C) 2020 by the authors. Licensee MDPI, Basel, Switzerland. This article is an open access article distributed under the terms and conditions of the Creative Commons Attribution (CC BY) license (http://creativecommons.org/licenses/by/4.0/). 